\title{
NUAK1 Gene
}

National Cancer Institute

\section{Source}

National Cancer Institute. NUAK1 Gene. NCI Thesaurus. Code C126571.

This gene plays a role in DNA damage response, apoptosis inhibition, cell adhesion,

cellular senescence, and cell proliferation. 